\title{
Children as Next of Kin in Higher Education: An Exploratory Cross-Sectional Study Among Health, Social Care, and Teacher Education Programs
}

\author{
Kari Almendingen (D)' \\ Anne Kristine Bergem (D) ${ }^{2}$ \\ Bente Sparboe-Nilsen (ID \\ Lisbeth Gravdal Kvarme ID \\ Jūratė Šaltytė Benth (D) ${ }^{3,4}$ \\ 'Department of Nursing and Health \\ Promotion, Faculty of Health Sciences, \\ OsloMet - Oslo Metropolitan University, \\ Oslo, Norway; ${ }^{2}$ Centre for Next of Kin \\ and Carers, Stavanger, Norway; ${ }^{3}$ Institute \\ of Clinical Medicine, Campus Ahus, \\ University of Oslo, Oslo, Norway; \\ ${ }^{4}$ Health Services Research Unit, Akershus \\ University Hospital, Lørenskog, Norway
}

Correspondence: Kari Almendingen Department of Nursing and Health Promotion, Faculty of Health Sciences, OsloMet - Oslo Metropolitan University, Oslo, Norway

Email kalmendi@oslomet.no
Introduction: Children who are "next of kin" (ie, sick/dying/addicted/imprisoned close relatives) are at increased risk for health consequences. Health professionals in Norway are required by law to help such children, and professional educations should focus on this issue. Aim: To assess the extent to which students attending health, social care, and teacher education felt their uni-professional education and a mandatory interprofessional learning (IPL) course had taught them about children as next of kin. To explore variations in student responses according to age and educational background.

Methods: This was a cross-sectional study. Students $(\mathrm{n}=2811)$ completed questionnaires relating to IPL courses delivered in 2019 and 2020 (hybrid case-based learning). Students discussed issues relating to interprofessional collaboration targeting children, young people and their families in small IPL groups.

Findings: The response rates ranged from $25.8 \%$ to $36.0 \%$. All but $5.2 \%$ of the students agreed that it was important to learn about children as next of kin. Although $61.9 \%$ reported that their education had not taught about such children, $73.8 \%$ had gained increased insight from the IPL course (difference 35.7\% 95\% CI $(29.0 ; 42.0), p<0.001)$. The teacher and child welfare students had gained greater insight than the health and social care students. Significant pre- to post-course increases were found among the physiotherapy $(p<0.001)$, Mensendieck physiotherapy $(\mathrm{p}<0.001)$, teacher education $(\mathrm{p}<0.001)$, early childhood education $(p<0.001)$, and teacher education in art and design $(p=0.042)$ students.

Conclusion: Nearly $2 / 3$ reported that they had not been taught about children as next of kin at their own educations, but more than $2 / 3$ had gained greater insight from the IPL course. The health and social care students reported the least gain. Although the law has existed for a decade, the topic of children as next of kin is still omitted from most educational programs.

Keywords: children as next of kin, children as relatives, health, social care, teachers, collaboration, interprofessional

\section{Plain Language Summary}

- Children are affected when someone in their family falls ill, is imprisoned, or uses substances. Children as next of kin are at increased risk for both short- and long-term health consequences. However, these children often remain invisible in the welfare system.

- In this study, relatively few of the students attending nine different health, social care, and teacher education programs reported having learned about children as next of kin during their programs, although the majority agreed it was important. After 
participation in an interprofessional course, most of the students reported having gained new insights into children as next of kin.

- Health professionals in Norway are required by law to help children who are next of kin. This study demonstrates a gap between the intentions of the Norwegian law amended in 2010, and its implementation in educational programs.

- The study supports an IPL approach because candidates from health, social care, and teacher education are expected to work with interprofessional competence when dealing with children, young people, and their families.

\section{Introduction}

When a parent or a child suffers from a serious illness, the whole family, including the underage siblings, are affected. $^{1-3}$ Children whose parents are suffering from substance abuse, mental illness, or somatic disease are all at risk for developing psychosocial problems and psychiatric or somatic diseases, and even early death. ${ }^{4-12}$ Having a parent in prison can also impact a child's mental health, social behavior, and educational prospects. ${ }^{13,14}$ The impact (short- or long-term) on the healthy siblings of sick children is shown to be associated with disease type, severity, and duration and age, sex, and ability to cope. ${ }^{15-17}$ Children as next of kin also perform more caregiving functions at home than other children do, with subsequent loss of quality of life. ${ }^{18}$

In Norway, 200,000 patients in somatic specialist health services are parents with responsibility for the daily care of children under the age of 18 . Of these, 29,000 are in psychiatric specialist care and 5000 in interdisciplinary drug treatment programs. ${ }^{19}$ Due to the consequences of family illness on children's' lives, the Norwegian government changed the Health Personnel Act in $2010 .^{20}$ Healthcare professionals in Norway have a duty to clarify if an adult patient has children, clarify the children's care situation and information needs, advise and guide the parents or others regarding the parental responsibilities, and plan and implement support measures in collaboration with the parents. ${ }^{21,22}$ Hospitals are required to have personnel responsible for children to promote and coordinate the support given by the health care professionals to patients who are parents and to their children. ${ }^{2,3,21,22}$ However, despite good intentions, willingness, and a favorable law, studies have shown that it is not easy for health professionals to pay attention to their adult patients' children. ${ }^{6,7,23-29}$ One study reported that although general practitioners are in a good position to help children as next of kin, these children easily remain invisible in the consultation with their parents. ${ }^{6}$ Support to a child who is burdened as next of kin depends often not on careful consideration of what is best for the patient and the child in the long run, but more on short-term convenience reasons. ${ }^{6}$

Society's demands for better coordination of services for children, young people and their families are increasing, and interprofessional learning (IPL) has been suggested to achieve the triple aim of better services, better outcomes and reduced costs. ${ }^{30}$ With the intention to bridge silos between the different services/laws, the Norwegian government amended laws that apply to all professionals working with children, stating that they are required to increase interprofessional collaboration (IPC) between the services. ${ }^{1}$ The law intends to reduce inadequate coordination and collaboration between the different services, and to prevent pulverization of liability. IPC must therefore be extended beyond health and social care professions to also include professions such as teaching and child welfare. ${ }^{1}$ Currently, students from education, health and social study programs, are mainly educated in educational trajectories which harbor different disciplinary professional identity, culture, tradition, syllabus etc, all of which may act as barriers for professional collaboration and teamwork. ${ }^{31}$ Knowledge boundaries between different professions in the welfare services includes differences in legislation, duties of confidentiality, but also different definitions, cultures, curriculum, procedures and knowledge bases. ${ }^{1}$ The topic children as next-of-kin is treated differently, also in countries where there has been done work for many years for these children. Understanding, definitions, and interventions differ, as do national politics. Bronfenbrenner's ecological systems theory ${ }^{32}$ highlights the complexity of interaction of individual, social and cultural elements, and is considered a useful framework that allows a comprehensive theoretically-grounded understanding of factors that enable/inhibit IPC. ${ }^{33,34}$ Sometimes, the health and social services must both be involved with the educational sector in order to prevent school dropouts for a range of reasons. $^{35-39}$ A study in schools reveals how school nurses can contribute to making the school a safe place for a child when a parent has a serious physical illness. ${ }^{40}$ A meta-analysis of 13 intervention studies found that, by increasing parenting skills and knowledge and by strengthening resilience factors among adolescents, the risk of children developing the same mental illness as 
their parents was reduced by $40 \%{ }^{41}$ Despite such knowledge and the legal requirement, children often experience a lack of information about their parent's illness or injury and what it will mean for them and their family. ${ }^{18,42}$ Compared to uni-professional healthcare teams, interprofessional healthcare teams are better equipped to improve patient outcomes, with input from each profession contributing to a better quality of life and improved patient safety. Research on children as next of kin, have mainly been restricted to health care. Despite the legislation, ${ }^{1,2}$ little is known about the extent to which teachers, health, and social care workers actually contribute to this important aspect of preventive work among children. Although teachers in an important part of children's life, to the best of our knowledge, no prior study has investigated whether students attending health, social care, and teacher education receive instruction about children as next of kin in their uni-professional programs.

This study is performed at Oslo Metropolitan University (OsloMet) which harbors the largest professional study programs in Norway. Students participated in a large-scaled IPL course, within an educational intervention which aims to meet society's demands for better coordination of services in relation to children and young people, better interaction between professionals, and better cooperation between children/young people and professionals. $^{31}$ As previously described, ${ }^{43}$ we applied social constructivist theory ${ }^{44}$ and a case-based smallgroup learning approach because this is considered an useful strategy for facilitating IPL. ${ }^{45}$ A socio-cultural constructivist approach is said to facilitate the move from teaching as content delivery to more student active learning with an increased learning outcome. ${ }^{44,46}$ IPL was introduced to have students from different professions learn with, from and about each other, in order to improve IPC. $^{30}$ When IPL is expanded beyond health care to include teachers and child welfare students, the latter will have a higher knowledge base on children, young people and their families. Although there is an identified need for educators to better prepare students for IPC, little has been reported on disciplinary differences in IPL preparedness with respect to unequal knowledge base on the topic children as next of kin. On this background, here is a knowledge gap regarding the extent to which students from teacher, health, and social care education are equally prepared for IPC through their pre-service training, and in particular, whether this training targets children as next of kin. The ongoing cross sectional study ${ }^{43}$ made it possible to investigate the students in health, social care and teacher educations preparedness to deliver serves to children as next of kind.

The aim of the study was to assess the extent to which pre-service students attending health, social care, and teacher education felt that their uni-professional study programs, including a shared large-scale mandatory IPL course, had taught them about working with children as next of kin. It also aimed to explore the extent to which the students' responses varied according to their age and educational background.

\section{Materials and Methods \\ Setting}

The data for this explorative quantitative cross-sectional study consisted of responses from bachelor's degree students participating in a compulsory large-scale blended IPL course (course name: INTER1100) in 2019 and 2020 at the Oslo Metropolitan University (OsloMet) in Norway. This course has been described in detail previously. ${ }^{43,47,48}$ In 2020, data were collected both pre- and post- the delivery of a course including the topic children and young people as next of kin, whereas in 2019, only postcourse data were collected. ${ }^{47}$ The IPL course is a part of an educational intervention entitled INTERACT (Interprofessional Interaction with Children and Young People) ${ }^{31}$, which aims to meet society's demands for better coordination of services in relation to children and young people, better interaction between professionals, and better cooperation between children/young people and professionals. $^{31}$ In Norwegian legal terms, a "child" means every person under 18 years of age. ${ }^{49}$ The term "young people" is often used for people up to 25 years of age. ${ }^{50}$ Challenges relating to modern childhood include obesity, fractured families, and issues related to use of the internet. The project organizers extended the IPL beyond health and social care to include teachers and child welfare workers, because these professions must all collaborate in real-life situations around children, young people, and their families.

\section{Participants}

The bachelor's degree students who participated were enrolled in the following study programs $(n=1401$ in 2019 and $n=1410$ in 2020): Early Childhood Education, Primary and Lower Secondary Teacher Education, Teacher Education in Art and Design, Physiotherapy, Mensendieck 
Physiotherapy, Nursing, Social Work, Child Welfare, and Occupational Therapy. The students enrolled were divided into pre-defined IPL groups, each consisting of eight students representing health, social care, and teacher education programs. The IPL course was mandatory, and thus no inclusion criteria were applied. Supervisors $(n=13)$ were recruited from among the staff, master's students and professionals working in the field. They were educated either as teachers $(n=9)$ or as health personnel (one nurse, two physios and one Mensendieck physiotherapist). ${ }^{48}$

\section{Blended Small Group Learning Course}

The required coursework included participation in a twoday seminar (working in the IPL groups only, with no plenary activities) and the submission of an IPL group assignment. The seminar days were structured as a combination of face-to-face IPL group discussion on campus and the use of digital learning materials provided by the learning management system (LMS) Canvas. The latter included case-based learning materials (produced by user organizations, employers, and public authorities) and mini-lectures (produced by staff and colleagues working in the field). Digital learning material was available prior to the IPL-course, so that the students could voluntarily prepare themselves individually before the IPL course, using a flipped classroom approach. ${ }^{51}$ The learning material included free online material provided by the Government $^{52}$ about parenthood, children's development and interaction between adults and children, specially prepared flipped classroom video lectures about developmental psychology produced by a psychiatrist, a concrete example from a municipality on how to observe children in kindergarten and school, a videoclip from Blue Cross illustrating a child as next of kin, ${ }^{53}$ and the Convention on the Rights of the Child ${ }^{49}$ presented in videoclips. The students were also introduced to a freely available digital platform for collaboration and competence sharing between municipalities, hospitals and educational institutions (Kompetansebroen.no). To understand how the inherent qualities of children and their environments interact and influence the growth and development of the children, participants were taught Bronfenbrenner's ecological systems theory. ${ }^{32,40}$ The topic of children as next of kin was introduced during the second day: the students first looked at a poster illustrating the 10 wishes of a child who was next of kin in a meeting with prison staff. ${ }^{54}$ The IPL groups were asked to discuss the content of the poster, including the question:
Why do you think that the same type of poster is made for different types of professionals who meet children and young people as next of kin in different contexts?

Second, they watched a videoclip (lasting $>2$ minutes) developed by the Centre for Next of Kin and Carers, ${ }^{55}$ which shows a dialogue between professionals after a mother has tried to commit suicide, and highlights relevant laws and ethics when children are next of kin. The discussion tasks were:

How are you going to work together as a team to make this child feel taken care of, and thus participate in and have an influence on decisions that concern his everyday life? What ethical dilemmas does this video clip address?

This session lasted for 45 minutes. In the next 45 -minute session, the students focused on IPC targeting children, young people, and their families. Students watched a governmental video (lasting $>2$ minutes) from a crosssectoral collaborative project ${ }^{56}$ aiming to achieve more coordinated and streamlined services for vulnerable children and young people, and a specially prepared video with a real-life example from a local municipality (lasting for 7 minutes). The IPL groups then discussed questions relevant to IPC, targeting children, young people, and their families, for example, "If interprofessional collaboration is the solution, then what is the problem?" As described previously, ${ }^{43}$ in the case-based IPL discussions, the students were required to play their future professional roles and to take note of each other's perspectives. Such case-based IPL discussions did not have a one correct answer but were designed to challenge the students to question their own knowledge and motivate them to seek new levels of understanding. This is a studentcentered form of teaching where the students' learning needs are at the center. The idea is to build knowledge for the future, and the immediate purpose is to create engagement among the students. ${ }^{43}$ The provision of the 2020 IPL course was repeated on the basis of the 2019 IPL course. ${ }^{43}$

\section{Online Evaluation Survey}

No suitable national or international questionnaire had been developed and /or validated in Norwegian. Hence, questions for the present study had to be specially prepared as part of larger questionnaires targeting students and supervisors. The questionnaires developed were based on quantitative research using an anonymous self-administrated web survey "Nettskjema",57 and previous research. ${ }^{43,47,58}$ Nettskjema is a tool for designing and conducting online surveys with 
customized features for research ${ }^{57}$ It is easy to use, and the respondents can submit answers from a browser on a computer, a mobile phone, or tablet. The questionnaires were tested and commented on by university college staff (academic and administrative) and one student, and revised accordingly. For the present study, an identical closed question was asked of the students after the IPL course delivery in both 2019 and 2020 (post- 2019, $\mathrm{n}=507$, and post- 2020, $\mathrm{n}=$ 363): "To what extent do you feel that the ILP course has given you better academic insight into children as next of kin?" Two closed questions were asked before the IPL course in 2020 (pre- 2020, $\mathrm{n}=454$ ): "To what extent have you learned about children as next of kin as part of your degree?' and "In the upcoming ILP course, to what extent do you think it is important to learn about children as next of kin?" (These questions were not included in a pre-2019 questionnaire). The students could respond on a scale from 0 , meaning "completely disagree", to 5 , meaning "completely agree". A closed question for the supervisors was also included after the IPL course in $2020(\mathrm{n}=13)$ : "To what extent do you feel that the ILP course has given the students a better academic insight into children as next of kin?" The student questionnaire was provided as an internet link embedded in the students' LMS, whereas the supervisor questionnaire was sent out via email. One reminder was sent to increase the response rate.

\section{Data Analysis}

The data were described as frequencies and percentages. Due to skewed distribution, the responses of students were dichotomized as either "agree" (score 3-5) or "disagree" (score 0-2). A z-test for proportions was applied to compare the dichotomized pre- and post- 2020 responses. The same test was also used to compare post- 2019 and post- 2020 responses. Analyses were further stratified by study program, dichotomized as either "Teacher education and child welfare" (consisting of Early Childhood Education and Care, Primary and Lower Secondary Teacher Education, Child Welfare, and Teacher Education in Art and Design, since those programs target only children and young people as end users) or as "Health and social care" (consisting of Physiotherapy, Mensendieck Physiotherapy, Nursing, Social Work, and Occupational Therapy, as those programs target all age groups as end users). The programs were also identified by a nine-category variable, and age was dichotomized as less than 25 or 25 years or older. For the sensitivity analyses, the scale was assumed to be continuous (0-5), and the independent samples $t$-test was applied rather than a z-test for proportions. All tests were two-sided, and results with p-values below 0.05 were considered statistically significant. No adjustment was made for multiple hypothesis testing due to the exploratory nature of the study. The statistical analyses were performed using the Statistical Package for the Social Sciences (SPSS) v27.

\section{Ethics}

The Ethical Guidelines for Research at OsloMet were followed. ${ }^{59}$ The study was also presented to the Norwegian Centre for Research Data (NSD) ${ }^{60}$ but they replied that it was unnecessary to report the study to them since it was completely anonymous and no sociodemographic information beyond the participants' ages and genders were collected (NSD reference number 741,649). None of the participants were under the age of 18 years. The data were collected through an anonymous web survey using Nettskjema, ${ }^{57}$ in line with the ethical guidelines. ${ }^{59}$ The participants were provided with written information about the study beforehand through the LMS Canvas. The voluntariness and anonymity of participation were emphasized, and participants were informed about the purpose of the study and how the data would be used. Answering the questionnaire was considered informed consent to participate. The study complied with the Declaration of Helsinki.

\section{Results}

\section{Demographic Characteristics}

The evaluation questionnaire was answered by students from all the study programs included, with a response rate of $36.0 \%$ (post- 2019), 32.2\% (pre- 2020), and $25.8 \%$ (post- 2020) (Table 1). Among the students, $48.3 \%$ (post- 2019), $43.8 \%$ (pre- 2020 ), and $46.0 \%$ (post2020) were taking the health and social care study programs. More than two-thirds of the respondents were under the age of 25 years in all three samples.

\section{Learned About Children as Next of Kin in Uni-Professional Study Programs}

One month ahead of the 2020 IPL course, $38.1 \%$ of students reported having learned something about children as next of kin (score 3-5) in their own study programs. In contrast, $61.9 \%$ reported that they had not learned about children as next of kin (scores 0-2) (Table 2).

The majority (94.7\%) agreed that it was important to learn about children as next of kin in the IPL course, whereas only $5.2 \%$ disagreed with this statement. 
Table I Characteristics of Students in a Large-Scale Blended Interprofessional Learning (IPL) Course Delivered in 2019 (Post 2019) and in 2020 (Pre and Post 2020). Numbers are Frequencies and Percentages

\begin{tabular}{|c|c|c|c|}
\hline Variable & $\begin{array}{l}\text { Post } 2019 \\
(\mathrm{~N}=507)^{\mathrm{a}}\end{array}$ & $\begin{array}{l}\text { Pre 2020 } \\
(N=454)\end{array}$ & $\begin{array}{l}\text { Post 2020 } \\
(\mathrm{N}=363)^{\mathrm{a}}\end{array}$ \\
\hline \multicolumn{4}{|l|}{ Age } \\
\hline 21 years or younger & $255(50.3)$ & $24 I(53.1)$ & $205(56.8)$ \\
\hline 22-24 years & $134(26.4)$ & $104(22.9)$ & $74(20.5)$ \\
\hline $25-27$ years & $63(12.4)$ & $42(9.3)$ & $34(9.4)$ \\
\hline$\geq 28$ years or older & $55(10.8)$ & $67(14.8)$ & $48(13.3)$ \\
\hline \multicolumn{4}{|l|}{ Study programs } \\
\hline Nursing & $50(9.9)$ & $47(10.4)$ & $35(9.6)$ \\
\hline Physiotherapy & $104(20.5)$ & 51 (1I.2) & $29(8.0)$ \\
\hline Mensendieck & $16(3.2)$ & & \\
\hline Physiotherapy & & $26(5.7)$ & $18(5.0)$ \\
\hline Teacher Education ${ }^{\mathrm{b}}$ & $133(26.2)$ & $108(23.8)$ & $92(25.3)$ \\
\hline Teacher Education in & NA & $28(6.2)$ & $23(6.3)$ \\
\hline Art and Design & & & \\
\hline Early Childhood & 95 (18.7) & $87(19.2)$ & $69(19.0)$ \\
\hline Education and Care & & & \\
\hline Occupational & $26(5.1)$ & $30(6.6)$ & $16(4.4)$ \\
\hline Therapy & & & \\
\hline Child Welfare & $34(6.7)$ & $32(7.0)$ & $35(9.6)$ \\
\hline Social work & $47(9.3)$ & $45(9.9)$ & $46(12.7)$ \\
\hline \multicolumn{4}{|l|}{ Age category } \\
\hline 25 years or younger & $389(76.7)$ & $345(76.0)$ & $279(77.3)$ \\
\hline 25 years or older & 118 (23.3) & $109(24.0)$ & $82(22.7)$ \\
\hline \multicolumn{4}{|l|}{$\begin{array}{l}\text { Study programme } \\
\text { category }\end{array}$} \\
\hline $\begin{array}{l}\text { Health and social } \\
\text { care }^{c}\end{array}$ & $245(48.3)$ & $199(43.8)$ & $167(46.0)$ \\
\hline $\begin{array}{l}\text { Teaching and child } \\
\text { welfare }^{d}\end{array}$ & $262(51.7)$ & $255(56.2)$ & $196(54.0)$ \\
\hline
\end{tabular}

Notes: ${ }^{2} 2019$ og 2020 post demographic data has been previously published. ${ }^{47,48}$

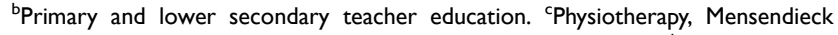
physiotherapy, nursing, social work and occupational therapy. ${ }^{\mathrm{d}}$ Early childhood education and care, primary and lower secondary teacher education, child welfare, and teacher education in art and design.

Abbreviations: NA, no answer; Pre, questionnaire data before IPL course delivery; Post, questionnaire data after IPL course delivery.

\section{Learned About Children as Next of Kin in IPL Course}

After the IPL course, $70.1 \%$ in 2019 and $73.8 \%$ in 2020 agreed (score 3-5), with no significant difference, that they now had better academic insight into children as next of kin. Only $29.9 \%$ and $26.2 \%$ disagreed with this statement (score $0-2$ ) in 2019 and 2020, respectively. The increase between pre2020 and post- 2020 scores in the proportion of students who had learned about children as next of kin was statistically significant (35.7\% 95\% CI $(29.0 ; 42.0), \mathrm{p}<0.001)$ (Table 3).

\section{To What Extent Do the Student Responses Vary According to Educational Background?} When comparing the proportion of students agreeing (scores 3-5) pre- and post- the 2020 course, there were significant increases, from $29.1 \%$ to $67.7 \%$ among the health and social care students and from $45.1 \%$ to $79.1 \%$ among the teacher and child welfare students (both $\mathrm{p}<$ 0.001) (Table 4).

The proportion of teacher and child welfare students reporting that they had gained increased insight into children as next of kin during the IPL course (score 3-5) increased significantly from 2019 to 2020 by $9.6 \%$ (95\% CI $(1.1 ; 17.7), p=0.021)$, while no such difference was found for the health and social care students.

The analysis was stratified according to study program as a nine-category variable, and this showed significant increases pre- to post- among students of Physiotherapy ( $p$ $<0.001)$, Mensendieck Physiotherapy $(\mathrm{p}<0.001)$, Teacher Education ( $\mathrm{p}<0.001)$, Early Childhood Education $(\mathrm{p}<$ 0.001), and Teacher Education in Art and Design ( $\mathrm{p}=$ 0.042). Moreover, the proportion of Early Childhood Education students with scores 3-5 increased from $65.3 \%$ in 2019 to $84.1 \%$ in $2020(\mathrm{p}=0.007)$, whereas the proportion of social work students with scores 3-5 reduced from $78.7 \%$ to $54.3 \%(\mathrm{p}=0.013)$ (Table 4$)$.

\section{To What Extent Did the Student Responses Vary According to Age?}

In both age categories (below and above 25 years), students had gained new academic insights about children as next of kin after the IPL 2020 course (both $\mathrm{p}<0.001$ ) (Table 5). Among the students below 25 years, slightly more students in 2020 than in 2019 had gained new academic insights about children as next of kin $(p=0.044)$.

\section{Sensitivity Analysis}

The results of the sensitivity analysis which assessed scores as continuous variables did not deviate from the analysis of the dichotomized answer alternatives.

\section{Supervisors}

The supervisors mainly agreed that the students had received better academic insight into children as next of kin: none of the supervisors chose the scores 0 or 1 . Of the 13 supervisors, $\mathrm{n}=1$ chose score $2, \mathrm{n}=5$ chose score 3 , $n=3$ chose score 4 , and $n=4$ chose score 5 . Thus, 12 of the 13 supervisors agreed (scores 3-5) that the IPL course 
Table 2 Distribution of Responses to Statements in a Large-Scale Blended IPL Course Delivered in 2019 and 2020 ("on a Scale from 0 to 5, State How Much You Agree or Disagree with the Following Statements, Where 0 Means “Completely Disagree" and 5 Means "Completely Agree"). Numbers are Frequencies and Percentages

\begin{tabular}{|c|c|c|c|c|c|c|c|}
\hline \multirow[t]{2}{*}{ Questions } & \multicolumn{7}{|l|}{ Scores } \\
\hline & 0 & I & 2 & 3 & 4 & 5 & Mean (SD) \\
\hline $\begin{array}{l}\text { Post 2019: To what extent do you feel that the ILP } \\
\text { course has given you a better academic insight into } \\
\text { children as next of kin? }(\mathrm{N}=507)^{\mathrm{a}}\end{array}$ & $15(3.0)$ & $45(8.9)$ & 91 (18.0) & 125 & $152(30.0)$ & 78 (15.4) & $3.2(1.3)$ \\
\hline $\begin{array}{l}\text { Pre 2020: To what extent have you learned about } \\
\text { children as next of kin as part of your degree? }(\mathrm{N}=454)\end{array}$ & $108(23.8)$ & $77(17.0)$ & $96(21.1)$ & 91 (20.0) & $58(12.8)$ & $24(5.3)$ & $2.0(1.5)$ \\
\hline $\begin{array}{l}\text { Pre 2020: In the upcoming ILP course, to what } \\
\text { extent do you think it is important to learn about } \\
\text { children as next of kin? }(N=454)\end{array}$ & $7(1.5)$ & $5(1.1)$ & $12(2.6)$ & $57(12.6)$ & II $(25.3)$ & $258(56.8)$ & $4.3(1.0)$ \\
\hline $\begin{array}{l}\text { Post 2020: To what extent do you feel that the ILP } \\
\text { course has given you a better academic insight into } \\
\text { children as next of kin? }(\mathrm{N}=363)\end{array}$ & $24(6.6)$ & $29(8.0)$ & 42 (11.6) & $96(26.4)$ & III (30.6) & $61(16.8)$ & $3.2(1.4)$ \\
\hline
\end{tabular}

Note: ${ }^{\text {PPre-data }}$ was not collected in the 2019 delivery.

Abbreviations: Pre, questionnaire data before course delivery; Post, questionnaire data after course delivery.

Table 3 To What Extent Do You Feel That the Interprofessional Learning (ILP) Course Has Given You a Better Academic Insight into Children as Next of Kin? Proportions and Differences in Proportions of Agreeing Students (Scores 3-5)

\begin{tabular}{|l|c|c|c|}
\hline & 2019 & 2020 & $\begin{array}{c}\text { Difference } \\
\text { 2020-20I9 } \\
\text { (\%) (95\% Cl) } \\
\text { p-value }\end{array}$ \\
\hline $\begin{array}{l}\text { Pre } \\
\mathrm{N}\end{array}$ & & 454 & \\
$3-5, \mathrm{n}(\%)$ & $173(38.1)$ & \\
$\begin{array}{l}\text { Post } \\
\mathrm{N}\end{array}$ & 506 & 363 & $3.7(-2.6 ; 9.8)$ \\
$3-5, \mathrm{n}(\%)$ & $355(70.2)$ & $268(73.8)$ & 0.238 \\
\hline $\begin{array}{l}\text { Difference Post- } \\
\text { pre in } \\
\text { proportion 3-5 } \\
\text { (\%) (95\% Cl) } \\
\text { p-value }\end{array}$ & $\mathrm{NA}$ & $35.7(29.0 ; 42.0)$ & \\
\hline
\end{tabular}

Note: ${ }^{\mathrm{a}} \mathrm{p}$-value for z-test for proportions.

Abbreviations: N, numbers; Pre, questionnaire data before IPL course delivery; Post, questionnaire data after IPL course delivery.

had given the students better academic insights into children as next of kin.

\section{Discussion}

Most of the students reported not having learned about children as next of kin as part of their undergraduate education. Almost all the students agreed that it was important to learn about this situation in relation to children. Approximately $2 / 3$ of the students reported having gained better academic insights into children as next of kin after the IPL course. The students from the health and social care education programs deviated from the students involved in teacher and child welfare education in that they had gained less information about children as next of kin both prior to and after the IPL course.

Less than $1 / 3$ of the health and social care students reported having learned about children as next of kin during their university education. The health students mostly meet adult patients during their practicum. Although most health care students will not work with children and young people as patients/clients in their future jobs, they will meet them as relatives of patients. ${ }^{22}$ Our concern is that all these educational programs need to strengthen their students' knowledge and skills in dealing with children as next of kin because all children have the right to receive adequate information, to be heard, and to have their say in matters that concern them. ${ }^{49}$ All candidates need to know about the increased risk of health consequences in both the short- and long-term for children with a parent or sibling who is sick, dying, or using substances. ${ }^{5-12,15-17}$ The children of imprisoned parents are also next of kin, and they are shown to have a two times greater risk of health problems and difficulties in their environment, academics, and behavioral problems in addition to social stigma. ${ }^{13,61,62}$ All professionals should identify at-risk children, including those who are next of kin, and ensure that they are adequately followed up, either within 
Table 4 To What Extent Do You Feel That the Interprofessional Learning (ILP) Course Has Given You a Better Academic Insight into Children as Next of Kin? Proportions and Differences in Proportions of Agreeing Students (Scores 3-5) Stratified by Health and Social Care Study Programs ${ }^{a}$ and Teacher and Child Welfare Study Programs ${ }^{b}$ and by Each of the Study Programs Separately

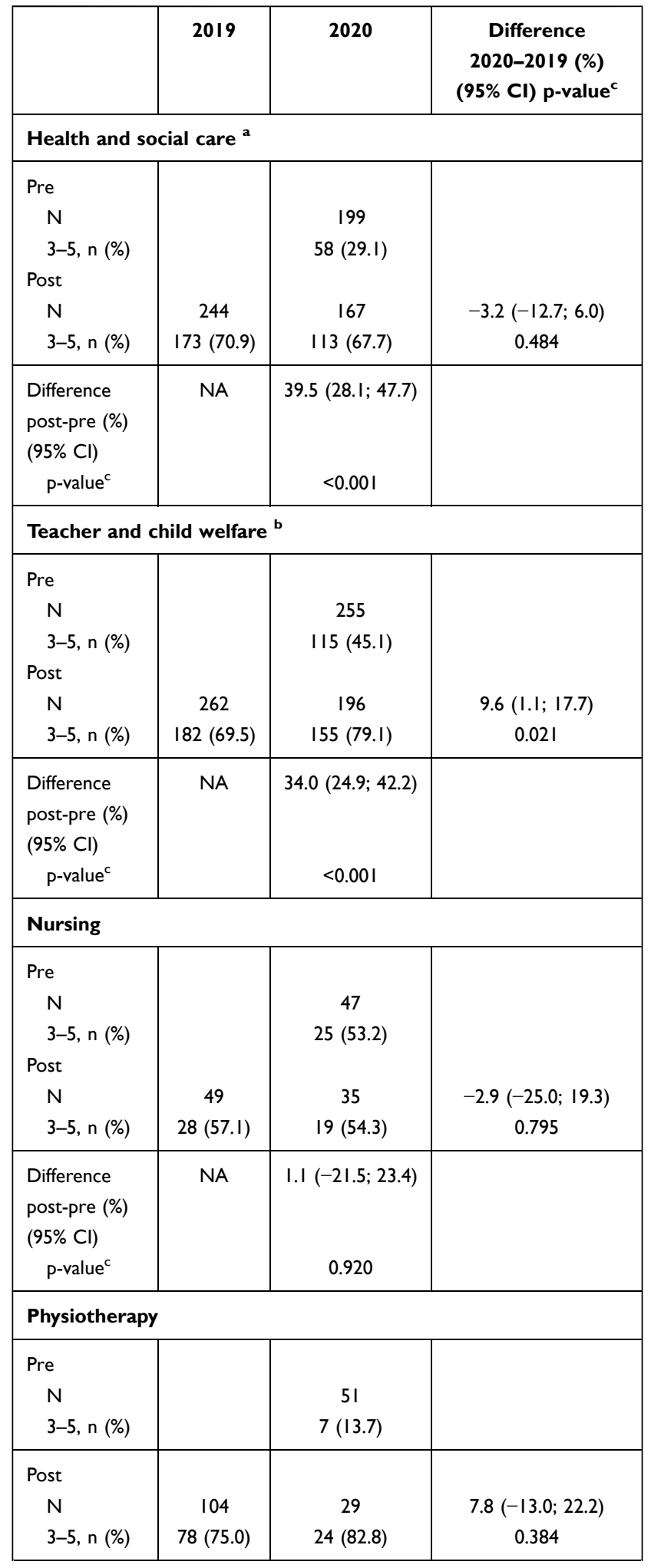

(Continued)
Table 4 (Continued).

\begin{tabular}{|c|c|c|c|}
\hline & 2019 & 2020 & $\begin{array}{c}\text { Difference } \\
2020-2019(\%) \\
(95 \% \mathrm{Cl}) \text { p-value }\end{array}$ \\
\hline $\begin{array}{l}\text { Difference } \\
\text { post-pre (\%) } \\
(95 \% \text { Cl) } \\
\text { p-value }^{c}\end{array}$ & NA & $\begin{array}{c}69.0(45.7 ; 82.2) \\
<0.001\end{array}$ & \\
\hline \multicolumn{4}{|c|}{ Mensendieck Physiotherapy } \\
\hline $\begin{array}{l}\text { Pre } \\
\mathrm{N} \\
3-5, \mathrm{n}(\%) \\
\text { Post }\end{array}$ & & $\begin{array}{c}26 \\
\mathrm{I}(3.8)\end{array}$ & \\
\hline $\begin{array}{l}N \\
3-5, n(\%)\end{array}$ & $\begin{array}{c}16 \\
12(75.0)\end{array}$ & $\begin{array}{c}18 \\
16(88.9)\end{array}$ & $\begin{array}{c}13.9(-16.3 ; 43.0) \\
0.289\end{array}$ \\
\hline $\begin{array}{l}\text { Difference } \\
\text { post-pre (\%) } \\
(95 \% \text { Cl) } \\
\text { p-value }^{c}\end{array}$ & NA & $\begin{array}{c}85.0(54.4 ; 94.9) \\
<0.001\end{array}$ & \\
\hline
\end{tabular}

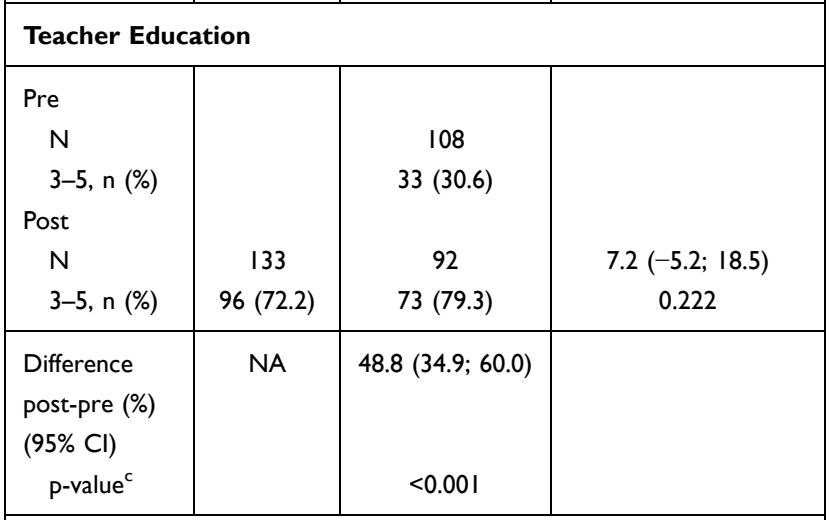

\begin{tabular}{|c|c|c|c|}
\hline \multicolumn{4}{|c|}{ Early Childhood Education } \\
\hline Pre & & & \\
\hline $\mathrm{N}$ & & 87 & \\
\hline $3-5, \mathrm{n}(\%)$ & & $46(52.9)$ & \\
\hline \multicolumn{4}{|l|}{ Post } \\
\hline $\mathrm{N}$ & 95 & 69 & $18.8(4.2 ; 31.6)$ \\
\hline $3-5, n(\%)$ & $62(65.3)$ & $58(84.1)$ & 0.007 \\
\hline Difference & NA & $31.2(15.7 ; 44.4)$ & \\
\hline post-pre (\%) & & & \\
\hline$(95 \% \mathrm{Cl})$ & & & \\
\hline$p$-value ${ }^{c}$ & & $<0.001$ & \\
\hline \multicolumn{4}{|c|}{ Occupational Therapy } \\
\hline \multicolumn{4}{|l|}{ Pre } \\
\hline $\mathrm{N}$ & & 30 & \\
\hline $3-5, \mathrm{n}(\%)$ & & $8(26.7)$ & \\
\hline \multicolumn{4}{|l|}{ Post } \\
\hline $\mathrm{N}$ & 26 & 16 & $-15.4(-45.0 ; 16.9)$ \\
\hline $3-5, n(\%)$ & $17(65.4)$ & $8(50.0)$ & 0.322 \\
\hline
\end{tabular}

(Continued) 
Table 4 (Continued).

\begin{tabular}{|c|c|c|c|}
\hline & 2019 & 2020 & $\begin{array}{c}\text { Difference } \\
2020-2019(\%) \\
(95 \% \mathrm{Cl}) \text { p-value }\end{array}$ \\
\hline \begin{tabular}{l} 
Difference \\
post-pre (\%) \\
$(95 \% \mathrm{Cl})$ \\
\multicolumn{1}{c}{ p-value }
\end{tabular} & NA & $\begin{array}{c}23.3(-8.0 ; 51.4) \\
0.114\end{array}$ & \\
\hline \multicolumn{4}{|c|}{ Child Welfare } \\
\hline $\begin{array}{l}\text { Pre } \\
\mathrm{N} \\
3-5, \mathrm{n}(\%) \\
\text { Post } \\
\mathrm{N} \\
3-5, \mathrm{n}(\%)\end{array}$ & $\begin{array}{c}34 \\
24(70.6)\end{array}$ & $\begin{array}{c}32 \\
17(53.1) \\
35 \\
24(68.6)\end{array}$ & $\begin{array}{l} \\
-2.0(-24.6 ; 21.0) \\
0.857\end{array}$ \\
\hline \begin{tabular}{l} 
Difference \\
post-pre (\%) \\
$(95 \% \mathrm{Cl})$ \\
\multicolumn{1}{c}{ p-value $^{\mathrm{c}}$}
\end{tabular} & NA & $\begin{array}{c}15.5(-9.6 ; 38.3) \\
0.194\end{array}$ & \\
\hline \multicolumn{4}{|l|}{ Social work } \\
\hline $\begin{array}{l}\text { Pre } \\
\mathrm{N} \\
3-5, \mathrm{n}(\%) \\
\text { Post } \\
\mathrm{N} \\
3-5, \mathrm{n}(\%)\end{array}$ & $\begin{array}{c}47 \\
37(78.7)\end{array}$ & $\begin{array}{c}45 \\
17(37.8) \\
\\
46 \\
25(54.3)\end{array}$ & $\begin{array}{l} \\
-24.4(-42.6 ;-3.6) \\
0.013\end{array}$ \\
\hline \begin{tabular}{l} 
Difference \\
post-pre (\%) \\
$(95 \% \mathrm{Cl})$ \\
\multicolumn{1}{c}{ p-value }
\end{tabular} & NA & $\begin{array}{c}16.6(-5.3 ; 36.4) \\
0.112\end{array}$ & \\
\hline Teacher Ed & :ion in Ar & and Design & \\
\hline $\begin{array}{l}\text { Pre } \\
\mathrm{N} \\
3-5, \mathrm{n}(\%) \\
\text { Post } \\
\mathrm{N} \\
3-5, \mathrm{n}(\%)\end{array}$ & & $\begin{array}{c}28 \\
19(67.9) \\
23 \\
21(91.3)\end{array}$ & NA \\
\hline \begin{tabular}{l} 
Difference \\
post-pre (\%) \\
$(95 \%$ Cl) \\
\multicolumn{1}{c}{ p-value $^{c}$}
\end{tabular} & NA & $\begin{array}{c}23.5(0.4 ; 43.0) \\
0.042\end{array}$ & \\
\hline
\end{tabular}

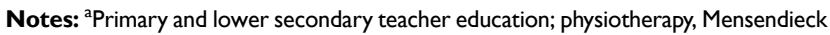
physiotherapy, nursing, social work and occupational therapy; 'bearly childhood education and care, primary and lower secondary teacher education, child welfare, and teacher education in art and design. ${ }^{c} \mathrm{p}$-value from z-test for proportions.

Abbreviations: N, numbers; Pre, questionnaire data before IPL course delivery; Post, questionnaire data after IPL course delivery.

their own profession or within a broader interprofessional setting. IPC can be challenging as different professions have different educational and professional cultures and varying approaches to dealing with challenges. ${ }^{30}$ Likewise, students from different educations may have diverse preparedness towards participation in the IPL, and therefore not the same learning outcomes. Still, an uni-professional educational approach is the dominant approach to train students. This means that the different study programs have different curriculum/syllabus and children are included in the learning outcomes in varying degrees. Mandatory uni-professional preparation ahead of IPL participation may even out some of the academic differences on children as next of kin in future IPL courses. Therefore, one strategy for overcoming barriers between different professionals is to reduce the knowledge boundaries between the professions through increasing the students IPL preparedness during uniprofessional study programs. The goal is an increased alignment in interprofessional activities with individual discipline curricula, so that students could see value in their disciplinary knowledge and the need for their active contribution in IPC case management. ${ }^{63}$ All professional educations should include children as next of kin in their study programs so the students get an understanding of such children. The preservice training must be relevant to complex real-life situations in order to prevent children who are next of kin remaining invisible to the professionals. We therefore suggest that children as next of kin should be included as a mandatory curricular topic in both uni-professional and IPL courses.

The higher learning outcome from the IPL course among the students from the teacher and child welfare education programs may have been influenced by a self-selection bias since these students may have had a particular interest in all aspects involving children and young people. Alternatively, the health and social care students may not have understood their professional responsibility toward this large group of vulnerable children when treating their parents or siblings. ${ }^{1,21}$ Bronfenbrenner's ecological systems theory ${ }^{32}$ and updated learning material on children as next of kin produced by government and relevant organizations ${ }^{54-56}$ were applied to enable the students to understand that different professional levels must interact to ensure the child's future health and well-being. Bronfenbrenner's systemic approach explain how structures where children have direct contact are referred to as a microsystem, including peers, family, community, and schools. The interaction between the microsystems occurs in the mesosystem. Bronfenbrenner's model helps understand the context of the child's situation, how the interaction between the different system levels affects the child, and the outcome of the intervention. 
Table 5 To What Extent Do You Feel That the Interprofessional Learning (ILP) Course Has Given You a Better Academic Insight into Children as Next of Kin? Differences Between 2019 and 2020 in Proportions of Agreeing Students (Scores 3-5), Stratified by Dichotomized Age

\begin{tabular}{|c|c|c|c|}
\hline & 2019 & 2020 & $\begin{array}{c}\text { Difference } 2020 \\
2019(95 \% \mathrm{Cl}) \\
\text { p-value }^{\mathrm{a}}\end{array}$ \\
\hline \multicolumn{4}{|c|}{25 years or younger } \\
\hline $\begin{array}{l}\text { Pre } \\
\qquad \begin{array}{l}\text { N } \\
3-5, n(\%)\end{array}\end{array}$ & & $\begin{array}{c}345 \\
\text { I } 37(39.7)\end{array}$ & \\
\hline Post & & & \\
\hline $\mathrm{N}$ & 389 & 279 & $7.1(0.2 ; 13.7)$ \\
\hline $3-5, n(\%)$ & $268(68.9)$ & $212(76.0)$ & 0.044 \\
\hline \begin{tabular}{l} 
Difference \\
post-pre (\%) \\
$(95 \% \mathrm{Cl})$ \\
\multicolumn{1}{c}{ P-value }
\end{tabular} & NA & $\begin{array}{c}36.3(28.8 ; 43.1) \\
<0.001\end{array}$ & \\
\hline \multicolumn{4}{|c|}{25 years or older } \\
\hline $\begin{array}{l}\text { Pre } \\
\qquad \mathrm{N} \\
3-5, \mathrm{n}(\%)\end{array}$ & & $\begin{array}{c}109 \\
36(33.0)\end{array}$ & \\
\hline Post & & & \\
\hline $\mathrm{N}$ & 117 & 82 & $-7.3(-20.1 ; 5.3)$ \\
\hline $3-5, n(\%)$ & $87(74.4)$ & $55(67.1)$ & 0.263 \\
\hline $\begin{array}{l}\text { Difference } \\
\text { post-pre (\%) } \\
(95 \% \mathrm{Cl}) \\
\text { p-value }^{\mathrm{a}}\end{array}$ & NA & $\begin{array}{c}34.1(19.9 ; 46.3) \\
<0.001\end{array}$ & \\
\hline
\end{tabular}

Note: ${ }^{\mathrm{a}} \mathrm{p}$-value from z-test which compares proportions between pre and post the same year and proportions between 2019 and 2020.

Abbreviations: N, numbers; Pre, questionnaire data before IPL course delivery; Post, questionnaire data after IPL course delivery.

However, our results showed that the teacher education and child welfare students agreed to a significantly higher degree that the learning resources, assignment, syllabus, and discussions were relevant to their future professional working lives. $^{47,48}$ In another IPL study, limited to health educations, students also expressed dissatisfaction with the lack of relevance of the case across disciplines. ${ }^{63}$ IPL interventions that challenge and reveal such differences could hopefully prepare all candidates for the complexity of working together in IPC teams when focusing on children, young people, and their families.

Our data do not agree with the suggestion ${ }^{64}$ that social workers and nurses have more undergraduate training than physicians and psychologists about following the new legal requirements ${ }^{1}$ relating to children as next of kin. That particular study investigated the family-focused practice of health professionals in all types of service (mental health, physical health, and substance abuse) and found significant differences between nurses, social workers, psychologists, and physicians, with overall better scores from the social workers and nurses. It also suggested that the social workers and nurses were more willing, or able due to time constraints, than the physicians and psychologists to follow the new legal requirements. Studies on health personnel in relation to their meeting children as next of kin indicate a general lack of structure and predictability in various settings, $6,7,26,27,29,40,65,66$ which may be explained by a lack of relevant pre-service training in higher education.

In accord with the students, the supervisors agreed that the students had gained increased insight about children as next of kin. The supervisors had supported the students in their communication and reflection and helped the group members to exchange ideas and find solutions they probably would not have found on their own. ${ }^{67}$ Although the sample size is too small to draw any conclusions regarding the supervisors, this is interesting since most of the supervisors were not educated as health personnel.

The learning objectives highlighted that the students would achieve "introductory knowledge" of children as next of kin. Any long-term effect on the students' future IPC skills, knowledge and competencies arising from this intervention is unknown. In Norway, from the academic year $2020 / 2021,{ }^{68}$ educational institutions are responsible for providing health and welfare students with education in IPL and on children (ie does not apply to these students, but next year's cohort). In teacher education programs in Norway, priority is given to three interdisciplinary themes: democracy and citizenship, sustainable development, and public health and well-being. ${ }^{69}$ OsloMet seized the opportunity to make the INTERACT project a part of its response to the new requirements for health and welfare students. ${ }^{68}$

Due to the shifts from inpatient to outpatient care in hospitals, and from hospitals to primary health care, an increased number of parents and siblings are receiving active treatment in their own homes. ${ }^{70}$ A decade ago, in 2010, Norway amended its Health Personnel Act so that health care personnel are now required to clarify whether patients have children and to ensure that the children's need for information and appropriate services are met. ${ }^{18}$ Rapid changes in the welfare care system require that graduates bring new knowledge to the practice setting. ${ }^{71}$ This study demonstrates that this already large - and probably 
increasing - vulnerable group of children is still nearly invisible in health, social care, and teacher education.

\section{Limitations and Strengths}

Self-selection bias may not be excluded, as responders with strong opinions - in either direction - may be present, yet the diversity in our sample enhances the robustness of the findings. The response rate was in line with a declining response rate to surveys in general, and this threatens the validity and generalizability of the findings. ${ }^{72,73} \mathrm{~A}$ high response rate is, however, no guarantee of sample quality. To overcome limitations due to selection bias, we used data from two consequent course deliveries in 2019 and 2020, and data from a large heterogeneous sample of students with different educational backgrounds. The students' responses were stable between 2019 and 2020. Stable responses for two consecutive years implies stability along the time axis. Further, the cross-sectional study design does not allow us to assess causality. The questions did not separate children as next of kin in different situations (mental or physical illness, substance abuse, death, imprisonment). The data collection was anonymous. Although the number of responding supervisors was only 13 (response rate $39.1 \%$ ), the supervisors' responses were in agreement with the responses of the students.

No other education institution in Norway could have performed this study because OsloMet harbors the largest professional study programs in Norway. Because the content in the curriculum for the respective educations is regulated by Norwegian government this study is applicable to other health care, social and teachers' educations in Norway. Moreover, since children as next of kin are not an isolated Norwegian phenomenon, findings could be of interest for health care, social and teachers' educations outside Norway.

In order to investigate professional candidates' preparedness for practice to deliver services to children as next of kin, future studies should investigate the content in professional curricula in higher education for example by using a manifest content analysis. ${ }^{74}$ An agreement between a content analysis and this study, would strengthen the conclusion of the present study. Future research should also explore how educators may counteract the knowledge boundaries between different professions (such as differences in legislation, duties of confidentiality, but also different definitions, cultures, curriculum, procedures and knowledge bases), ${ }^{1}$ in order to prepare the different student groups ahead of IPL targeting children-related topics: The teacher education and child welfare students are more familiar with children and young people as a user group, which may explain why these students to a significantly higher degree agreed that the learning resources, assignment, syllabus and discussions were relevant. ${ }^{48}$ The teacher education and child welfare students had gained more insight into the WHO's core IPL competencies (roles and responsibilities, values and ethics, interprofessional communication, and teams and teamwork) than the health and social care students after the IPL course. ${ }^{48}$ User participation from services and from end users is essential for providing educations that meets the needs of society and employers. In-depth studies are needed to focus on the special needs of children as next of kin to ensure their welfare and prevent harm. Bronfenbrenner's ecological systems theory ${ }^{32}$ has been found useful for its multi-system approach to understanding IPL/IPC enablers/inhibitors. Bronfenbrenner's ecological system concepts can result in recommendations that are useful for guiding public health policy and practice, ${ }^{34}$ but such an analysis is beyond the scope of this study.

\section{Conclusion}

The students had learned only to a minor extent about children as next of kin in their uni-professional study programs, but the majority of the participants agreed that it is important to learn about such children. Most of the students gained better academic insight into children as next of kin during the IPL course. When comparing the students' groups, the teacher and child welfare students reported more positively on their learning in the uniprofessional study programs and during the IPL course than the health and social care students. Age was of minor importance. This study is applicable to other health care, social and teachers' educations in Norway. Further on, focus on children as next of in education could also be of interest for health care, social and teachers' educations outside Norway.

\section{Acknowledgments}

We first wish to thank the participants. We also wish to thank the academic and administrative staff at Oslo Metropolitan University for their contribution to this work. Special thanks go to the administrative manager of INTERACT, Ellen Merethe Magnus, and to the project manager of INTERACT, Torhild Skotheim.

\section{Disclosure}

The authors report no conflicts of interest in this work. 


\section{References}

1. Lov om endringer i velferdstjenestelovgivningen (samarbeid sob. Lov om endringer i velferdstjenestelovgivningen (samarbeid, samordning og barnekoordinator). In: Ministry of Education and Research, editor. Lovdata; 2021. Available from: https://lovdata.no/dokument/LTI/lov/ 2021-06-11-78. Accessed November 19, 2021.

2. Vi - de pårørende. Regjeringens pårørendestrategi og handlingsplan; 2020.

3. Nasjonal veileder om pårørende i helse- og omsorgstjenesten; 2021.

4. Felitti VJ, Anda RF, Nordenberg D, et al. Relationship of childhood abuse and household dysfunction to many of the leading causes of death in adults: the Adverse Childhood Experiences (ACE) Study. Am J Prev Med. 1998;14(4):245-258. doi:10.1016/S0749-3797(98) 00017-8

5. Jakobsen IS, Christiansen E. Young people's risk of suicide attempts in relation to parental death: a population-based register study. $J$ Child Psychol Psychiatry. 2011;52(2):176-183. doi:10.1111/ j.1469-7610.2010.02298.x

6. Gullbrå F, Smith-Sivertsen T, Rortveit G, Anderssen N, Hafting M. To give the invisible child priority: children as next of kin in general practice. Scand J Prim Health Care. 2014;32(1):17-23. doi:10.3109/ 02813432.2014 .874133

7. Knutsson S, Enskär K, Andersson-Gäre B, Golsäter M. Children as relatives to a sick parent: healthcare professionals' approaches. Nord J Nurs Res. 2017;37(2):61-69. doi:10.1177/20571585 16662538

8. Bröning S, Kumpfer K, Kruse K, et al. Selective prevention programs for children from substance-affected families: a comprehensive systematic review. Subst Abuse Treat Prev Policy. 2012;7:23. doi:10. 1186/1747-597X-7-23

9. Hjern A, Berg L, Arat A, et al. Children as next of kin in Sweden; 2017. Available from: https://www.anhoriga.se/Global/BSA/ Dokument/Rapporter_kunskaps\%C3\%B6versikter/2017-2_BSArapport.pdf. Accessed November 15, 2021.

10. Niemelä M, Hakko H, Räsänen S. A systematic narrative review of the studies on structured child-centred interventions for families with a parent with cancer. Psychooncology. 2010;19(5):451-461. doi:10. 1002/pon. 1620

11. Reupert AE, Cuff R, Drost L, Foster K, Van Doesum KTM, Van Santvoort F. Intervention programs for children whose parents have a mental illness: a review. Med J Aust. 2013;199(S3):S18-S22. doi:10.5694/mja11.11145

12. Boullier M, Blair M. Adverse childhood experiences. Paediatr Child Health. 2018;28(3):132-137. doi:10.1016/j.paed.2017. 12.008

13. Heinecke Thulstrup S, Eklund Karlsson L. Children of imprisoned parents and their coping strategies: a systematic review. Societies. 2017;7(2):15.

14. Clopton KL, East KK. "Are there other kids like me?" Children with a parent in prison. Early Child Educ J. 2008;36(2):195-198. doi:10.1007/s10643-008-0266-z

15. Dinleyici M, Dağlı FŞ. Evaluation of quality of life of healthy siblings of children with chronic disease. Turk Pediatri Ars. 2018;53(4):205-213. doi:10.5152/TurkPediatriArs.2018.6778

16. Fleary SA, Heffer RW. Impact of growing up with a chronically ill sibling on well siblings' late adolescent functioning. ISRN Family Med. 2013;2013:737356. doi:10.5402/2013/737356

17. Sharpe D, Rossiter L. Siblings of children with a chronic illness: a meta-analysis. J Pediatr Psychol. 2002;27(8):699-710. doi:10.1093/ jpepsy/27.8.699

18. Kallander EK. Children affected by parental illness or parental substance abuse: young carers, well-being and quality of life; 2019. Available from: file://C:/Users/kalmendi/Downloads/PhD-Kallander -2020.pdf. Accessed November 15, 2021.
19. Ruud T, Birkeland B, Faugli A, et al. Barn som pårørende - Resultater fra en multisenterstudie. IS-0522; 2015. Available from: https://www. helsedirektoratet.no/rapporter/barn-som-parorende-resultater-fra-enmultisenterstudie/Barn $\% 20$ som $\% 20 \mathrm{p} \% \mathrm{C} 3 \% \mathrm{~A} 5 \mathrm{r} \% \mathrm{C} 3 \% \mathrm{~B} 8 \mathrm{rende} \% 20 \%$ E2\%80\%93\%20Resultater\%20fra\%20en\%20multisenterstudie.pdf/_ attachment/inline/80ae6065-0af7-4daa-a6b7-57e6fb2949a 8: dad0550eeafb0d50eacdd3662f66ba833bd5dc05/Barn\%20som $\% 20 \mathrm{p} \%$ C3\%A5r\%C3\%B8rende\%20\%E2\%80\%93\%20Resultater\%20fra\% 20en\%20multisenterstudie.pdf. Accessed November 15, 2021.

20. The health personnel act; 2000.

21. Spesialisthelsetjenesteloven. Specialized Health Services Act. Lovdata; 1999.

22. The health personnel act. Lovdata; 1999.

23. Karidar H, Åkesson H, Glasdam S. A gap between the intention of the Swedish law and interactions between nurses and children of patients in the field of palliative oncology - the perspective of nurses. Eur J Oncol Nurs. 2016;22:23-29. doi:10.1016/j.ejon.2016.01.005

24. Hjelmseth $\mathrm{M}$, Aune T. Uklare rammer gjør det vanskelig å ivareta barn som pårørende. Sykepleien Forskning. 2018;13:e-65521. doi:10.4220/Sykepleienf.2018.65521

25. Tillquist M, Bäckrud F, Rosengren K. Dare to ask children as relatives! A Qualitative Study about female teenagers' experiences of losing a parent to cancer. Home Health Care Manag Pract. 2016;28 (2):94-100. doi:10.1177/1084822315610104

26. Karidar H, Glasdam S. Inter-professional caring for children who are relatives of cancer patients in palliative care: perspectives of doctors and social workers. Br J Soc Work. 2018;49(3):595-614. doi:10. 1093/bjsw/bcy080

27. Holmberg P, Nilsson J, Elmqvist C, Lindqvist G. Nurses' encounters with children as next of kin to parents with a cancer diagnosis on oncology wards. Nord J Nurs Res. 2019;40. doi:10.1177/205715 8519868437

28. Hjelde KH, Guribye E, Magnussen M-L, Ali W. Oppfølging av barn som pårørende i familier med innvandrerbakgrunn. 2015:3. Available from: https://www.fhi.no/globalassets/dokumenterfiler/rapporter/ 2015/hjelde-et-al-2015-barn-som-innvandrerbakgrunn-nakmi-rapport -nr-3-2015.pdf. Accessed September 07, 2021.

29. Hultsjö S, Hjelm K. Immigrants in emergency care: Swedish health care staff's experiences. Int Nurs Rev. 2005;52(4):276-285. doi:10. $1111 / \mathrm{j} .1466-7657.2005 .00418 . x$

30. WHO. Framework for action on interprofessional education \& collaborative practice; 2010. Available from: https://apps.who.int/iris/bit stream/handle/10665/70185/WHO_HRH_HPN_10.3_eng.pdf;jsessio nid $=6404$ FD35BF759397105FD11F092CD504? sequence $=1$. Accessed November 15, 2021.

31. INTERACT. INTERACT (Interprofessional Interaction with Children and Youth). Available from: https://uni.oslomet.no/interact/ . Accessed October 07, 2020.

32. Bronfennbrenner U. The Ecology of Human Development Experiments by Nature and Design. Harvard University Press; 1979.

33. Bluteau P, Clouder L, Cureton D. Developing interprofessional education online: an ecological systems theory analysis. $J$ Interprof Care. 2017;31(4):420-428. doi:10.1080/13561820.2017.1307170

34. Eriksson M, Ghazinour M, Hammarström A. Different uses of bronfenbrenner's ecological theory in public mental health research: what is their value for guiding public mental health policy and practice? Soc Theory Health. 2018;16(4):414-433. doi:10.1057/s41285-0180065-6

35. Strunk J, Dr D, Pavelko S, et al. Interprofessional education for pre-service school-based professionals: faculty and student collaboration. Teach Learn Commun Sci Disord. 2019;3(1). doi:10.30707/TLCSD3.1Strunk

36. Barnard-Brak L, Stevens T, Carpenter J. Care coordination with schools: the role of family-centered care for children with special health care needs. Matern Child Health J. 2017;21(5):1073-1078. doi:10.1007/s10995-016-2203-x 
37. Brenner M, Kidston C, Hilliard C, et al. Children's complex care needs: a systematic concept analysis of multidisciplinary language. Eur J Pediatr. 2018;177(11):1641-1652. doi:10.1007/s00431-0183216-9

38. National guideline for health promotion and preventive work in the child and youth health centres and school health service, $0-20$ years (Helsedirektoratet), 2017.

39. Borg E, Drange I. Interprofessional collaboration in school: effects on teaching and learning. Improv Sch. 2019;22(3):251-266. doi:10.1177/ 1365480219864812

40. Golsäter M, Enskär K, Knutsson S. Contributing to making the school a safe place for the child: school nurses' perceptions of their assignment when caring for children having parents with serious physical illness. Nurs Open. 2017;4(4):267-273. doi:10.1002/nop2.92

41. Siegenthaler E, Munder T, Egger M. Effect of preventive interventions in mentally ill parents on the mental health of the offspring: systematic review and meta-analysis. $J$ Am Acad Child Adolesc Psychiatry. 2012;51(1):8-17.e8. doi:10.1016/j. jaac.2011.10.018

42. Järkestig Berggren $U$, Hanson E. Children as next of kin: a scoping review of support interventions for children who have a parent with a serious physical illness. Child Care Pract. 2016;22(3):277-295. doi:10.1080/13575279.2015.1102125

43. Almendingen K, Šaltytė Benth J, Molin M. Large scale blended learning design in an interprofessional undergraduate course in Norway: context description and supervisors' perspective. MedEdPublish. 2021;10(1):1. doi:10.15694/mep.2021.000162.1

44. Vygotsky LS. Mind in Society: The Development of Higher Psychological Processes. Gyldendal Akademisk; 1978.

45. Curran VR, Sharpe D, Forristall J, Flynn K. Student satisfaction and perceptions of small group process in case-based interprofessional learning. Med Teach. 2008;30(4):431-433. doi:10.1080/01421590 802047323

46. Lillejord S, Børte K. Learning and teaching with technology in higher education - a systematic review; 2018. Available from: https://www. forskningsradet.no/siteassets/publikasjoner/1254035532334.pdf. Accessed February 20, 2021.

47. Almendingen K, Molin M, Šaltytė Benth J. Large-scale blended learning design in an undergraduate interprofessional course in Norway: students' Perspectives from an Exploratory Study. $J$ Res Interprof Pract Educ. 2021;11(1):1-26. doi:10.22230/jripe.2021v1 ln1a319

48. Almendingen K, Nilsen B, Kvarme L, Saltyte Benth J. Core competencies for interprofessional collaborative practice among teacher education, health and social care students in a large scaled blended learning course. $J$ Multidiscip Healthc. 2021;14:2249-2260. doi:10. 2147/JMDH.S325086

49. United Nations. Convention on the rights of the child. Available from: https://www.ohchr.org/en/professionalinterest/pages/crc.aspx. Accessed August 26, 2021.

50. The child welfare act; 1992.

51. Evans L, Vanden Bosch ML, Harrington S, Schoofs N, Coviak C. Flipping the classroom in health care higher education: a systematic review. Nurse Educ. 2019;44(2):74-78. doi:10.1097/nne.00000 00000000554

52. The Norwegian Directorate for Children YaFAB. Foreldrehverdag Trygge råd til deg med barn. Available from: https://www.bufdir.no/ Foreldrehverdag/. Accessed November 15, 2021.

53. Blå Kors Norge - La barn være barn! Blåkors. Available from: https:// www.youtube.com/watch? $\mathrm{v}=$ _C58MN9n9LQ. Accessed September 17, 2021.

54. BarnsBeste - Nasjonalt kompetansenettverk for barn som pårørende. 10 ønsker fra et pårørende barn i møte med fengselsansatte. Available from: https://sshf.no/seksjon/BarnsBeste/ Documents/Kunnskapsbanken/Plakat_10-r\%C3\%A5d-fengsel.pdf. Accessed August 28, 2021.
55. Pårørendeprogrammet. Barn som pårørende. Available from: https:// www.youtube.com/watch?v=w_itC3Lx_6o. Accessed August 28, 2021.

56. 0-24 samarbeidet. "Stian" - 0-24 samarbeidet. Available from: https://vimeo.com/291453010. Accessed August 28, 2021.

57. Nettskjema. University of Oslo. Available from: https://www.uio.no/eng lish/services/it/adm-services/nettskjema/. Accessed June 21, 2021.

58. Almendingen K, Molin M, Šaltytė Benth J. Preparedness for interprofessional learning: an exploratory study among health, social care, and teacher education programs. $J$ Res Interprof Pract Educ. 2021;11 (1):1-11. doi:10.22230/jripe.2021v11n1a309

59. Oslo Metropolitan University (OsloMet). Ethical guidelines for research at Oslo Metropolitan University (OsloMet). Available from: https://ansatt.oslomet.no/documents/585743/53632647/Ethical +Guidelines+for+Reserach+at+OsloMet/3dccee65-e17e-04f6-34d3a8e 58f280c88. Accessed June 21, 2021.

60. Database for Statistics on Higher Education (DBH). Available from: https://dbh.nsd.uib.no/statistikk/rapport.action?visning Id= $234 \&$ visKode $=$ false \&admdebug $=$ false $\&$ columns $=$ arstall! $!$ !finmodko de\&index $=1 \&$ formel $=999 \&$ hier=insttype 9 ! instkode! 9 ! progkode $! 9$ ! emnekode\&sti $=\&$ param $=$ arstall\%3D2020!9!Semester\%3D3!9!dep id\%3D1!9!nivakode\%3DB3!8!B4!8!HK!8!YU!8!AR!8!LN!8!M2!8! ME!8!MX!8!HN!8!M5!8!PR. Accessed January 20, 2021.

61. Paynter M, Jefferies K, McKibbon S, Martin-Misener R, Iftene A, Murphy GT. Mother child programs for incarcerated mothers and children and associated health outcomes: a scoping review. Nurs Leadersh. 2020;33(1):81-99. doi:10.12927/cjnl.2020.26189

62. Bradshaw D, Creaven A-M, Muldoon OT. Parental incarceration affects children's emotional and behavioral outcomes: a longitudinal cohort study of children aged 9 to 13 years. Int J Behav Dev. 2021;45 (4):310-316. doi:10.1177/0165025421995918

63. van Diggele C, Roberts C, Haq I. Optimising student-led interprofessional learning across eleven health disciplines. BMC Med Educ. 2021;21(1):157. doi:10.1186/s12909-021-02527-9

64. Skogøy BE, Ogden T, Weimand B, Ruud T, Sørgaard K, Maybery D. Predictors of family focused practice: organisation, profession, or the role as child responsible personnel? BMC Health Serv Res. 2019;19 (1):793. doi:10.1186/s12913-019-4553-8

65. Golsäter M, Henricson M, Enskär K, Knutsson S. Are children as relatives our responsibility? - how nurses perceive their role in caring for children as relatives of seriously ill patients. Eur J Oncol Nurs. 2016;25:33-39. doi:10.1016/j.ejon.2016.09.005

66. Fearnley R, Boland JW. Communication and support from health-care professionals to families, with dependent children, following the diagnosis of parental life-limiting illness: a systematic review. Palliat Med. 2017;31 (3):212-222. doi:10.1177/0269216316655736

67. Lindqvist S, Vasset F, Iversen HP, Hofseth Almas S, Willumsen E, Odegard A. University teachers' views of interprofessional learning and their role in achieving outcomes - a qualitative study. $J$ Interprof Care. 2019;33(2):190-199. doi:10.1080/13561820.2018.1534809

68. Ministry of Education and Research. National curriculum Regulations for Norwegian Health and Welfare Education (RETHOS). https://www.regjer ingen.no/en/topics/education/higher-education/nasjonale-retningslinjerfor-helse-og-sosialfagutdanningene-rethos/id2569499/. Accessed August 27, 2021.

69. Ministry of Education and Research. The school of the future: renewal of subjects and competences. Official Norwegian Reports NOU 2015; 2015:8. https://www.regjeringen.no/contentassets/ da 148 fec 8 c 4 a 4 ab 88 daa 8 b 677 a $700292 /$ en-gb/pdfs / nou201520150008000engpdfs.pdf. Accessed November 15, 2021.

70. The coordination reform - proper treatment - at the right place and right time (The government); 2009.

71. Quality culture in higher education; 2017.

72. The Norwegian Agency for Quality Assurance in Education. The students' judgement. Available from: https://www.nokut.no/en/ news/the-students-judgement/. Accessed September 09, 2019. 
73. Morton SMB, Bandara DK, Robinson EM, Carr PEA. In the 21 st century, what is an acceptable response rate? Aust N Z J Public Health. 2012;36(2):106-108. doi:10.1111/j.17536405.2012.00854.x
74. Hsieh H-F, Shannon SE. Three approaches to qualitative content analysis. Qual Health Res. 2005;15(9):1277-1288. doi:10.1177/ 1049732305276687

\section{Publish your work in this journal}

The Journal of Multidisciplinary Healthcare is an international, peerreviewed open-access journal that aims to represent and publish research in healthcare areas delivered by practitioners of different disciplines. This includes studies and reviews conducted by multidisciplinary teams as well as research which evaluates the results or conduct of such teams or healthcare processes in general. The journal covers a very wide range of areas and welcomes submissions from practitioners at all levels, from all over the world. The manuscript management system is completely online and includes a very quick and fair peer-review system. Visit http://www.dovepress.com/testimonials. php to read real quotes from published authors. 